
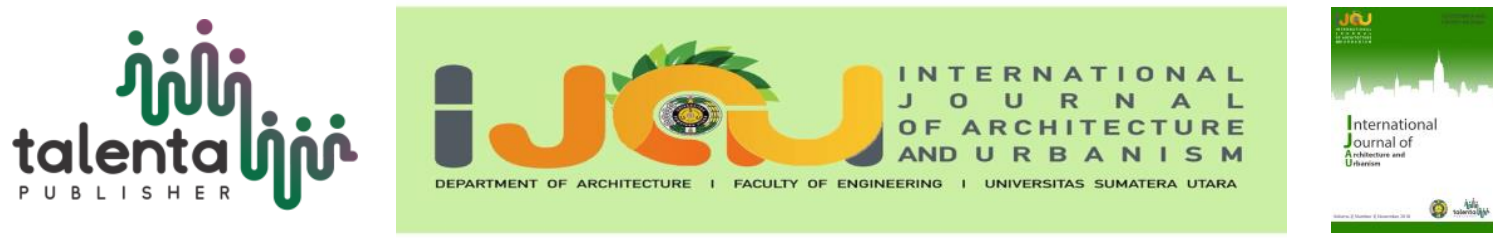

\title{
The Effect of The Coastal District of Social Perspectives In The Kampung Nelayan Indah Belawan Medan
}

\author{
B O Y Marpaung ${ }^{*}$, Mahmudatun Nisa Daulay ${ }^{I}$ \\ ${ }^{1}$ Architecture Department, Faculty of Engineering, Universitas Sumatera Utara, Medan, Indonesia
}

\begin{abstract}
A person's views or beliefs affect space in the coastal environment. The settlement in the Kampung Nelayan Indah Belawan Medan was built because of the government's assumption in building the settlement and spatial planning in the coastal area. The space formed in the settlement is adapted to the pattern of community activities that occupy it to facilitate local people in doing their work outside the room. The coastal areas also affect the social perspectives of people living in settlements. Social views arise because of age, education, socioeconomic, socio-cultural, counseling. Researchers use quantitative methods in analyzing the public perception and social view of the reality of space formed in the Kampung Nelayan Indah Belawan Medan. While the qualitative method used to analyze the factors affect the different views between occupants.
\end{abstract}

Keyword: Coastal areas, social perspective, space

\section{Introduction}

The settlement of Kampung Nelayan Indah Belawan Medan is a formal settlement built by the government in the framework of government policy programme. The government's policy is realized in the form of the housing program for low-income fishermen. The existence of housing programme in the coastal area caused by the increase of a population in the coastal area causing the increase of the land requirement to adequate public activity marked by spreading of space contained in the settlement. The pattern of space built by the government in the settlement has sufficient needs of community activities. Government-built settlements in coastal areas will generate a social perspective on the reality of the space it occupies.

\section{Literatur Review}

Researchers completed this research using qualitative methods. The researchers conducted a direct observation of the occupants who occupy the houses in the settlement of Kampung Nelayan Indah Belawan Medan. Researchers who make observations to make maps of people

*Corresponding author at: Department of Architecture, Faculty of Engineering, Universitas Sumatera Utara, Jalan Perpustakaan, Gedung J07, Medan, 20155, Indonesia

E-mail address: beny.marpaung@usu.ac.id 
who have livelihoods of fishermen and non-fishermen. Researchers also distributed questionnaires to the public. An objective question in collecting information about people's perceptions of the settlements and people's point of view on the reality of the existing space. The researchers linked the questionnaire statistics with physical facts in the field. In carrying out the analysis, researchers connect the results of data interpretation on a theoretical basis. Through observation, the researcher will produce an invention that substantially has a relationship with the public view.

\section{Methodology}

Rural settlements and evolved from the functional view of the traditional spaces of society (forms and patterns) embodied by the historical, political, social and cultural factors that make up the rearrangement of rural settlement system [1]. Society as a social scope that becomes a container of the patterns of social interaction that develops following the norms and values of life becomes its characteristics for traditional societies arranged in social structure [2]. Social interaction has an impact on balanced community life. Balanced community life in urban areas can reveal the complexity of urban sustainability [3]. A social perspective can cultivate a view of reality if the shared beliefs of the reference group with that one peculiar affiliation and group are formulated from external social ties and influence [4]. The social capital perspective on fisheries governance suggests that there must think again of funding priorities and mechanisms from "top-down" fisheries management to "collective management" with a focus on the fulfillment of rights and responsibilities for fishermen and their communities [5]. Functional perspectives apply settlement analysis in rural areas, an increasing number of residences, residential dispersion patterns, area differentiation, and hierarchical structures. The pattern of space in the settlements can affect the common pattern of attendance and mutual awareness of the collection of people who inhabit and visit the settlement [6]. Society generally has sensing and interpretation of the stimulus of an informed object or event, so that one can perceive, interpret, and interpret the stimuli it receives according to the state itself and the environment in which it exists, to determine its action [7]. Factors that influence people's perception are (1) stimulus objects, (2) personal factors, (3) group influence factors, and (4) cultural background factors [8]. The consequences of these coastal pressures include management problems arising from utilization conflicts that result in various interests in coastal areas. There are several groups of coastal settlements mostly dependent on fishing by working as fishermen. There are also some other groups of people who are bolstering their lives as merchants and hurrying the industry [9]. Risks associated with coastal settlements are related to changing weather conditions, including storms, erosion, flooding and the need to improve property maintenance. This risk is emphasized by climate change for some time [10]. 


\section{Result and Discussion}

People living in Kampung Nelayan Indah Belawan Medan generally have different viewpoints in occupying the settlements. Before Kampung Nelayan Indah Belawan Medan can be occupied, there are government policies that apply to occupy the settlement (Figure 2). The inhabitants of a beautiful fishing village that can occupy the settlements are people who have livelihoods as fishermen. However, over time, people who settled in the settlement of fishing village in Belawan Medan began to be inhabited by people who are not professions as fishermen, such as traders, private employees, civil servants and others (Figure 1). From the changes arising from the perspective of people who settled in the settlement. The public perception of the environment he occupies is influenced by how long he occupies the settlement. A place to live has a role in building the human point of view that occupies it. The point of view can also be influenced by other factors such as age, education, livelihood and so on. The inhabitants of the village have a point of view that one day their settlement will be better than before. Implementation of coastal development in the coastal area with the emergence of some views about the residence that form the pattern of space in it. The pattern of space contained in the settlement allows residents to meet with neighbors because the position of the adjacent house allows people to mutually greet each other (Figure 3). The pattern of space in the settlement can also affect the presence of residents to gather.

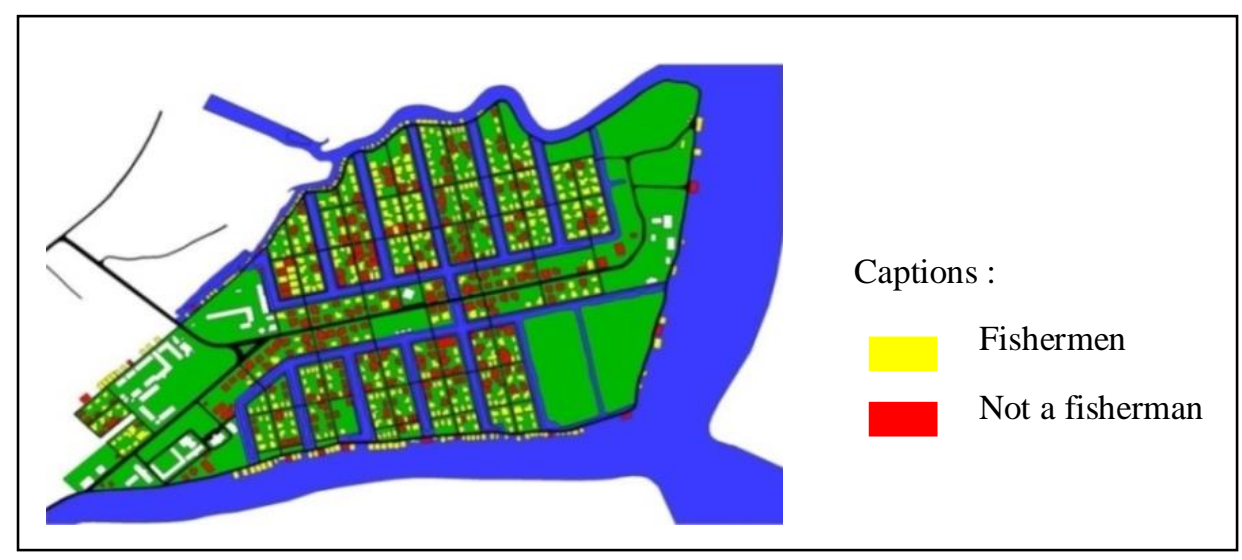

Figure 1. Map position of Building based on Livelihood in Fishing Village Indah Belawan Medan 


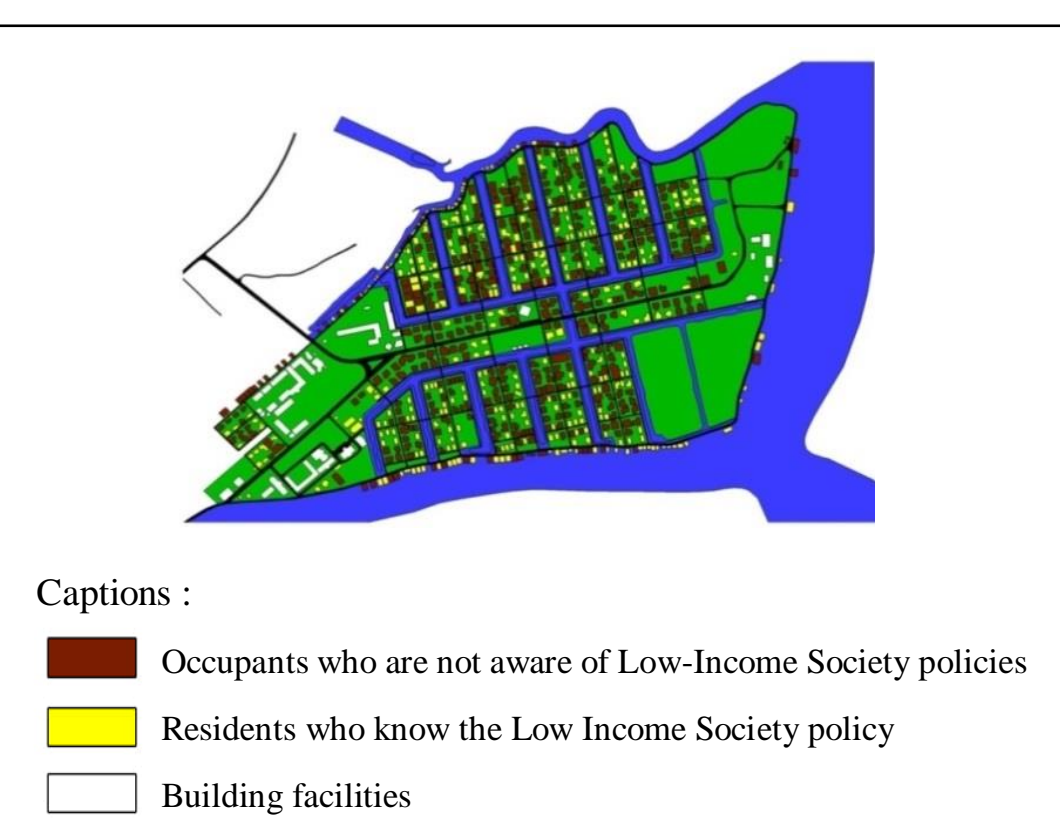

Figure 1. Map of Knowledge of the Occupants About For the Low-Income Community Housing

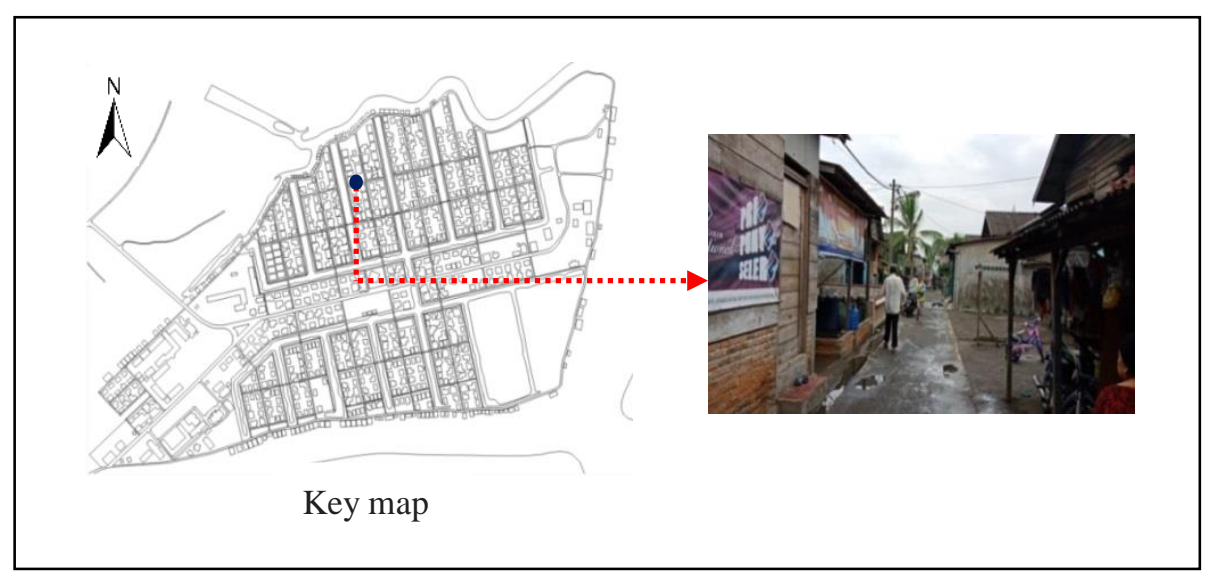

Figure 3. The position of a house that is easy to meet with neighbors in the settlement

Settlements that are inhabited by communities are government-built settlements. According to the perspective of social perspectives, the settlements are built not by what they want. Problems arising in coastal areas due to lack of employment triggered the occurrence of criminal acts/theft in the settlement of Kampung Nelayan Indah Belawan Medan. Criminal or the actions that occur in the beautiful fishermen because some residents who settled in the settlement generally do not have a permanent job. On the other hand, the problem also occurs in coastal areas due to changing weather factors, including storms, erosion, floods, and ups and downs of seawater causing flooded settlements and the non-permanent fisherman's occupation makes residents do not go sailing. The problems that occur can affect the perspective view of social communities that occupy the settlement. The settlements of Kampung Nelayan Indah Belawan Medan formed due to the management residential area so that the space formed in the settlement is well structured and adapted to community activities. The road is one of the spaces where residents are used as a place to carry out the celebration because the space contained in the house is not 
sufficient to accommodate the inhabitants who come. With the narrow space in the settlement, the area makes it easier for people to chat with each other neighbors. The quality of open spaces found in the settlements is very bad as the parks are located in unmaintained settlements, and lack of park facilities such as park benches, foot reflexology courses, children's slide and so on make the lazy people go to safety. The settlement of Kampung Nelayan Indah Belawan Medan is built and in accordance with the needs of the fishermen community. However, there are some communities who have the view that the government-built settlements are not as they want them to be.

\section{Conclusion}

Kampung Nelayan Indah Belawan Medan was a formal settlement located in Kelurahan Nelayan Indah and Kecamatan Medan Labuhan. Occupancy built is on land, but still, in coastal areas, settlements are built with government policy programs. One of the government's policy programs is the construction of a Kampung Nelayan Indah Belawan Medan. The settlement was built for three years and opened in 1994 with the number of simple houses of 1,444 units of 21,27 and 36 types inhabited by fishermen from Medan Labuhan and Medan Marelan subdistricts. Settlements are built to reduce slums around the seafront and occupancy is reserved for people who have a livelihood as fishermen and have low income. Housing built by the government is adjusted to the activities of the fishing community marked by the number of spreading spaces that accommodate community activities. With the construction of housing in the coastal area is marked by the emergence of the social perspective of the people who occupy it. The fact of space in the traditional settlements formed in accordance with the expected residents can be seen from the spreading of space contained in the settlement of Kampung Nelayan Indah Belawan Medan in accordance with the activities of the community settlement community. The study found that people who have the view that the narrow space pattern in the settlement facilitate residents meet with neighbors. Because the position of the adjacent house makes it easy for people to greet each other. Coastal areas affect the social perspective of the people who live there because consciously people will feel the impact of what they do on the physical form of the environment. The impact of community involvement will generate various perceptions from each or community group that occupies it. Researchers also found that weather factors affect coastal areas because the erratic weather will make fishing catches uncertain so many fishermen who do not go sailing and become unemployed. The criminal action also occurs because a large number of residential residents generally do not have a permanent job.

\section{Acknowledgment}

Study on The Effect of The Coastal District of Social Perspectives In The Kampung Nelayan Indah Belawan Medan is the Research result of a cooperation of the Lectures and students at the Architecture Department Faculty of Engineering, Universitas Sumatera Utara, Medan. 


\section{REFERENCES}

[1] S. K. Nepal, "Tourism and rural settlements Nepal's Annapurna region," Ann. Tour. Res., vol. 34, no. 4, pp. 855-875, 2007.

[2] E. Edwar, Edwar, Pergeserang tanggung jawab Mamak kepada Kepala Waris terhadap Anak Kemenakan pada Masyarakat Pariaman Perantauan menurut E (2010). 2010.

[3] M. Biddulph, "The limitations of the urban village concept in neighbourhood renewal: A Merseyside case study," Urban Des. Int., vol. 8, no. 1, pp. 5-19, 2003.

[4] A. Bandura, "Social cognitive theory of mass communication," Media Eff. Adv. theory Res., pp. 94-124, 2009.

[5] N. U. Sekhar, "Social capital and fisheries management: The case of Chilika Lake in India," Environ. Manage., vol. 39, no. 4, pp. 497-505, 2007.

[6] B. Hillier, Space is the machine - a configurational theory of architecture. 2007.

[7] T. Muchtar, "Hubungan Karakteristik Elit Formal dan elit Informal Desa dengan Persepsi dan Tingkat Partisipasi Mereka dalam program P3DT di Kabupaten Sukabumi."

[8] A. Sattar, "Persepsi Masyarakat Pedesaan Terhadap Usaha Konservasi Sumberdaya Alam dan Lingkungan Di DAS Bila Walanae Sulawesi Selatan," Persepsi Masyarakat Pedesaan Terhadap Usaha Konserv. Sumberdaya Alam dan Lingkungan Di DAS Bila Walanae Sulawesi Selatan, 1985.

[9] G. Budhya and S. Benjamin, "The politics of sustainable cities: The case of Bengare, Mangalore in coastal India," Environ. Urban., vol. 12, no. 2, pp. 27-36, 2000.

[10] C. Leger, C. Balch, and S. Essex, "Understanding the Planning Challenges of Brownfield Development in Coastal Urban Areas of England," Plan. Pract. Res., vol. 31, no. 2, pp. 119-131, 2016. 